\title{
CYTOTOXICITY AND GENOTOXICITY OF RESIN BASED DENTAL MATERIALS IN HUMAN LYMPHOCYTES IN VITRO
}

\author{
Valentina Brzović Rajić ${ }^{1}$, Davor Želježić ${ }^{2}$ Ana Malčić Ivanišević ${ }^{1}$, \\ Željko Verzak ${ }^{3}$, Anja Baraba ${ }^{1}$ and Ivana Miletić ${ }^{1}$
}

${ }^{1}$ Department of Endodontics and Restorative Dentistry, School of Dental Medicine, Zagreb University Hospital Center, Zagreb, Croatia; ${ }^{2}$ Institute for Medical Research and Occupational Health, Zagreb, Croatia; ${ }^{3}$ Department of Pediatric and Preventive Dentistry, School of Dental Medicine, Zagreb University Hospital Center, Zagreb, Croatia

SUMMARY - The aim of this in vitro study was to evaluate cytotoxicity and genotoxicity of six different dental nanocomposite materials, three conventional ones and three flowable composite resin materials, in human lymphocytes. The following materials were tested: Tetric EvoCeram, Tetric EvoFlow, Filtek Ultimate, Filtek Ultimate Flow, G-aenial and G-aenial Flo. Cytotoxicity was evaluated for two mass concentrations $(0.007 \mathrm{~g} / \mathrm{mL}$ and $0.013 \mathrm{~g} / \mathrm{mL})$ of each material, non-cured and cured, after 4 hours and 24 hours. Genotoxicity was evaluated using micronucleus assay under the same conditions as applied during the investigation of cytotoxicity. Uncured forms of Tetric EvoCeram, Tetric EvoFlow and Filtek Ultimate Flow in higher mass concentration caused genotoxic effect. Uncured G-aenial Flo in higher mass concentration induced apoptosis and necrosis. Uncured Tetric EvoFlow and uncured Filtek Ultimate Flow in higher mass concentration induced early apoptosis after both test periods. None of the conventional composite resin materials tested showed cytotoxicity except for uncured G-aenial, which induced apoptosis in higher mass concentration in both test periods. In conclusion, under the conditions of this in vitro study, cured conventional composites did not show cytotoxic or genotoxic effect, which is important for clinical application of these materials, whereas uncured forms exhibited certain level of cytotoxicity and genotoxicity, mainly because of monomers in their composition.

Key words: Dental Materials; Nanocomposites; Composite Resins; Cytotoxins; Apoptosis

\section{Introduction}

Composite resin materials are routinely used for various applications in dental restorative procedures. Although dental composites are continuously developing, these materials still typically consist of a methacrylate-based resin matrix, glass or ceramic fillers and a filler-matrix coupling agent ${ }^{1}$. The conventional or-

Correspondence to: Prof. Željko Verzak, DMD, PhD, University of Zagreb, School of Dental Medicine, Department of Pediatric and Preventive Dentistry, Gundulićeva 5, HR-10000 Zagreb, Croatia E-mail:verzak@sfzg.hr

Received April 19, 2017, accepted April 18, 2018 ganic matrix widely used in composites is generally based on methacrylate chemistry like bisphenol A glycol dimethacrylate (Bis-GMA), triethylene glycol dimethacrylate (TEGDMA), and urethane dimethacrylate (UDMA) ${ }^{2}$. It seems that the organic matrix is responsible for adverse effects regarding biocompatibility of dental composites ${ }^{3}$. The polymerization reaction that produces the cross-linked polymer matrix from the dimethacrylate resin monomer is never complete and adverse reactions occur due to the release of non-polymerized monomers ${ }^{3}$. These monomers can produce cytotoxic effect of resin composites on pulp and gingival cells, and also implicate the possible al- 
lergic reactions to the material ${ }^{4}$. The two mechanisms result in segregation of the components from resinous dental materials. After polymerization, unbound monomers are extracted by saliva or drinks containing solvents, especially during the first 24 hours 5 . However, leachable substances may also be generated by erosion and degradation caused by photo, thermal, mechanical, or chemical influences ${ }^{5}$. Darmani et al. ${ }^{6}$ showed that the cytotoxicity levels of dental composites may vary depending on the type and amount of the components they contain.

Recently, evolution of dental composites has altered their filler size, introducing nanofilled and nanohybrid composite resin materials on the market. Since the dimensions of these filler particles are below those of visible light, it is impossible for them to either scatter or absorb visible light, which enables excellent aesthetic properties of the material and higher filler load is responsible for excellent physical-mechanical properties ${ }^{7}$.

The aim of this in vitro study was to evaluate cytotoxicity and genotoxicity of six different dental nanocomposite materials, three conventional ones and three flowable composite resin materials, in human lymphocytes.

\section{Materials and Methods}

\section{Blood sampling}

Blood was collected from a 27-year-old female, healthy, non smoking voluntary donor who signed an informed consent. A single-donor approach was implemented to avoid unnecessary dispersion of the results as the consequence of potential inter-individual differences in the intensity of cellular response to the genotoxic agent. The donor completed a questionnaire confirming she had not been exposed to any physical or chemical agent in the 12 -month period prior to blood sampling that may have interfered with the results of genotoxicity testing. Blood was drawn by antecubital venipuncture into heparinized vacutainers (Becton Dickinson, Plymouth, UK). Lymphocytes were isolated from the blood sample by centrifugation (700 $\mathrm{xg}$ for $20 \mathrm{~min}$ ) on Histopaque-1077 (Sigma-Aldrich, Munich, Germany), and washed twice with RPMI 1640 medium (Gibco Invitrogen, UK) prior to the treatment and cultivation.

\section{Preparation of composite resin materials}

In the present study, the following six composite resin materials were tested: Tetric EvoCeram, Tetric EvoFlow, Filtek Ultimate, Filtek Ultimate Flow, G-aenial and G-aenial Flo. Each material was tested on human peripheral blood lymphocytes using the micronucleus assay and ethidium bromide/acridine orange viability staining. Polymerization of all composite resin materials was done with a LED Bluephase lamp (Vivadent, Ivoclar, Schaan, Lichenstein) for 20 s using the soft start program. For each material, eluates of two different mass concentrations of $0.007 \mathrm{~g} / \mathrm{mL}$ and $0.013 \mathrm{~g} / \mathrm{mL}$ were obtained. Immediately after loading, the tubes with composite resin materials, $3 \mathrm{~mL}$ of RPMI 1640 medium (Invitrogen, Paisley, UK) was added in each tube. Two different elution periods of 4 hours and 24 hours were applied.

\section{Cell treatment}

After each elution period, $3 \mathrm{~mL}$ of the eluate was loaded into a new sterile tube (Greiner, Frickenhausen, Germany) and $100 \mu \mathrm{L}$ of lymphocyte isolate containing 100 cells $/ \mu \mathrm{L}$ was introduced. Lymphocytes were treated for 4 hours at $37^{\circ} \mathrm{C}$ according to the OECD testing guideline (OECD, 1997). Negative control culture of lymphocytes was exposed only to RPMI 1640 medium for 4 hours.

After the treatment period, cultures were centrifuged for $3 \mathrm{~min}$ at $1000 \mathrm{rpm}$, the supernatant was discarded, and cells were transferred into a sterile tube. They were resuspended in $3 \mathrm{~mL}$ of RPMI 1640 medium. The process of lymphocyte centrifugation and washing with fresh medium was repeated twice. After second centrifugation, cells were resuspended and 10 $\mu \mathrm{L}$ of suspension was transferred to microscopic glass (Tlos, Zagreb, Croatia) for cytotoxicity testing.

\section{Cytotoxicity testing}

Ten $\mu \mathrm{L}$ of lymphocyte suspension on the microscopic glass was mixed with $10 \mu \mathrm{L}$ of acridine orange $(10 \mathrm{mg} / \mathrm{mL}) /$ ethidium bromide solution $(10 \mathrm{mg} / \mathrm{mL})$, covered by cover slip and analyzed under the epifluorescence microscope (BX 50, Olympus, Tokyo, Japan) using 400x magnification. For each testing, 200 lymphocytes were analyzed in duplicate. Nuclei of vital cells emitted green fluorescence, early apoptotic lymphocytes emitted green fluorescence with hypercon- 
densed chromatin regions, late apoptotic cells red fluorescence with hypercondensed chromatin regions, and necrotic red normally condensed nuclei.

\section{Micronucleus assay}

After taking $10 \mu \mathrm{L}$ of cell culture for cytotoxicity testing, the remaining lymphocytes were cultivated in 5 mL RPMI 1640 (Invitrogen, Paisley, UK), adding 1 $\mathrm{mL}$ of fetal bovine serum (Gibco, Paisley, UK), $0.1 \mathrm{~mL}$ of phytohemagglutinin, $100 \mathrm{IU}$ penicillin (Sigma, St. Louis, USA) and 100 IU streptomycin (Sigma-Aldrich, Munich, Germany) and incubated in Falcon chamber (BD Bioscience, California, USA) at $37^{\circ} \mathrm{C}$ and $5 \%$ of $\mathrm{CO}_{2}$. At the $44^{\text {th }}$ hour of cultivation, cytochalasin $\mathrm{B}$ was added to the cell culture at a concentration of $6 \mu \mathrm{g} / \mathrm{mL}$ in order to stop cytokinesis. At 72 hours of cultivation, cultures were centrifuged for 10 min at $600 \mathrm{rpm}$, the supernatant was discarded and cells were resuspended in $5 \mathrm{~mL}$ of fixative acetic acid (Kemika, Zagreb, Croatia) and methanol (Kemika, Zagreb, Croatia), w/w 1:3. Cells were transferred to microscopic glass, air-dried and stained with 5\% Giemsa for $10 \mathrm{~min}$. Analysis was performed by using a light microscope (Olympus CX 40, Olympus, Tokyo, Japan) under magnification of 1000x. For each material and elution period, 1000 binuclear lymphocytes were analyzed for micronuclei content, nuclear buds and nucleoplasmic bridges.

\section{Statistical analysis}

The $\chi^{2}$-test was used to test difference in the number of micronuclei, nuclear buds, nucleoplasmic bridges, apoptotic, necrotic and viable cells between the treated and negative control lymphocytes. Statistical significance was set at the level of $\mathrm{p}<0.05$. Statistical analysis was performed by using Statistica 5.0 (StatSoft, Oklahoma, USA).

\section{Results}

After 4 hours and 24 hours, uncured and cured Tetric EvoFlow in mass concentration of $0.013 \mathrm{~g} / \mathrm{mL}$
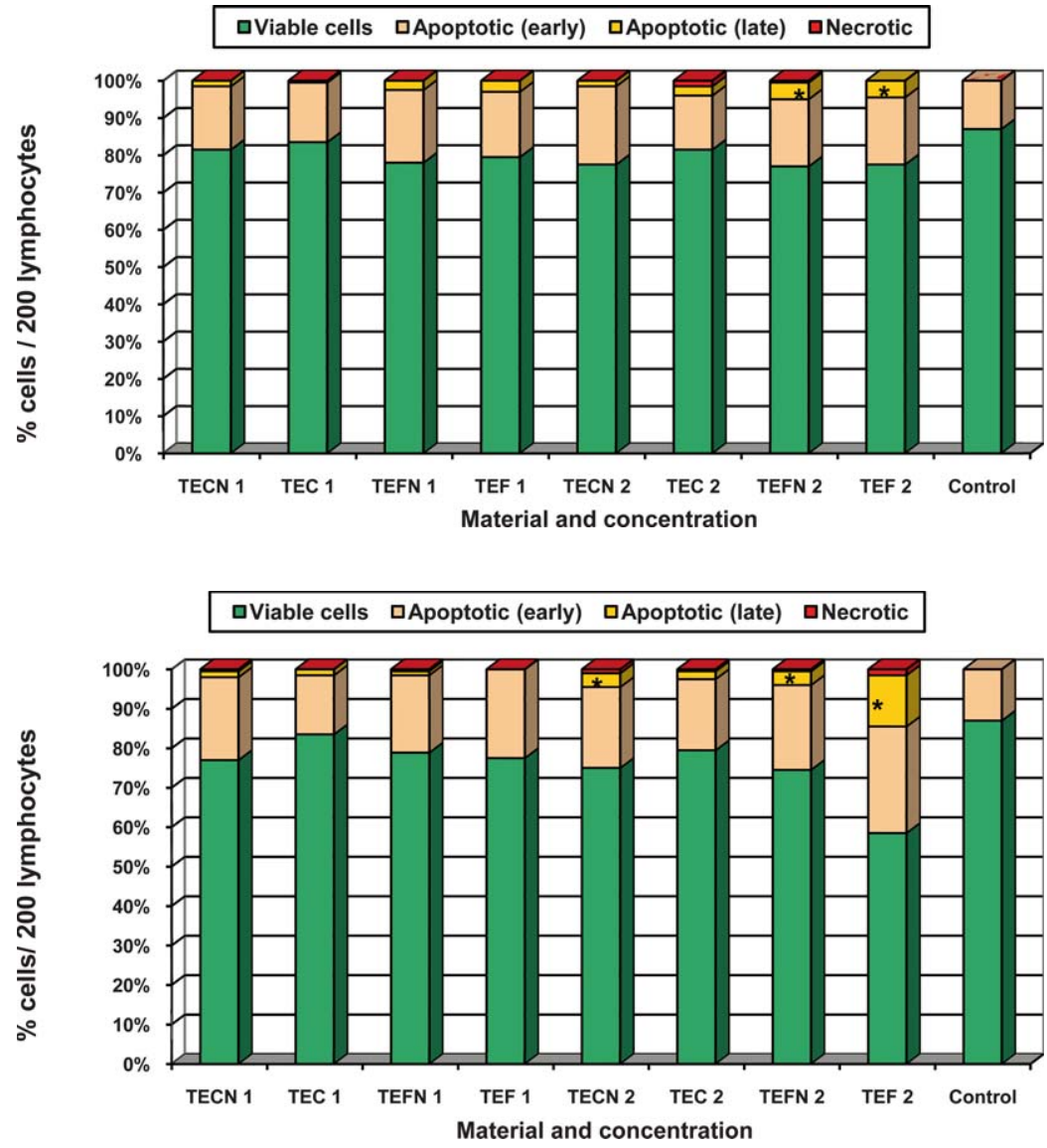

Fig. 1. Cytotoxic effect of Tetric EvoCeram (TEC) and Tetric EvoFlow (TEF) in both mass concentrations $(0.007 \mathrm{~g} / \mathrm{mL}$ (1) and $0.013 \mathrm{~g} / \mathrm{mL}(2))$ polymerized (TEC1, TEF1, TEC2, TEF2) and unpolymerized (TECN1, TEFN1, TECN2, TEFN2) after 4 hours; ${ }^{*}<0.05$.

Fig. 2. Cytotoxic effect of Tetric EvoCeram (TEC) and Tetric EvoFlow (TEF) in both mass concentrations $(0.007 \mathrm{~g} / \mathrm{mL}$ (1) and $0.013 \mathrm{~g} / \mathrm{mL}(2))$ polymerized (TEC1, TEF1, TEC2, TEF2) and unpolymerized (TECN1, TEFN1, TECN2, TEFN2) after 24 hours; ${ }^{*} p<0.05$. 
Fig. 3. Cytotoxic effect of Filtek Ultimate (FU) and Filtek Ultimate Flow (FUF) in both mass concentrations $(0.007 \mathrm{~g} / \mathrm{mL}$ (1) and $0.013 \mathrm{~g} / \mathrm{mL}(2))$ polymerized (FU1, FUF1, FU2, FUF2) and unpolymerized (FUN1, FUFN1, FUN2, FUFN2) after 4 hours; ${ }^{*} p<0.05$.

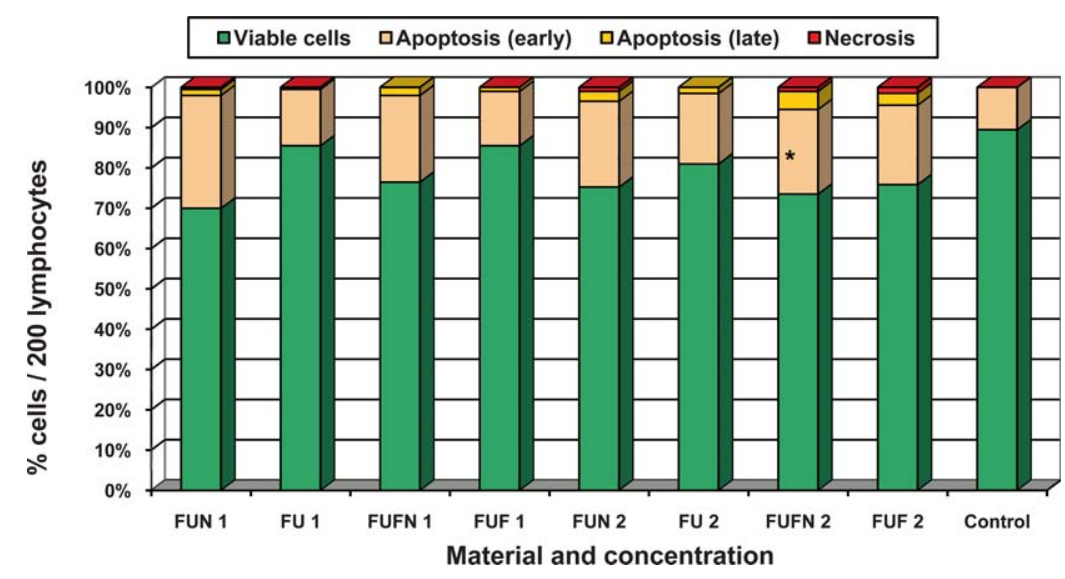

Fig. 4. Cytotoxic effect of Filtek Ultimate (FU) and Filtek Ultimate Flow (FUF) in both mass concentrations $(0.007 \mathrm{~g} / \mathrm{mL}$ (1) and $0.013 \mathrm{~g} / \mathrm{mL}(2))$ polymerized (FU1, FUF1, FU2, FUF2) and unpolymerized (FUN1, FUFN1, FUN2, FUFN2) after 24 hours; ${ }^{*} p<0.05$.

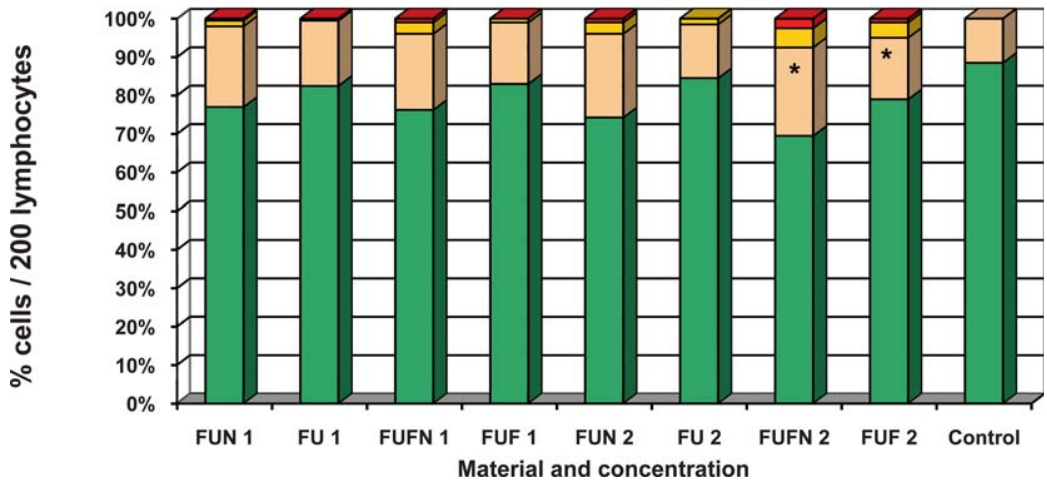

significantly decreased cell survival by inducing early apoptosis ( $<0.05)$ (Figs. 1 and 2). In both test periods, uncured Filtek Ultimate Flow in higher mass concentration exhibited less viable cells undergoing early apoptosis $(\mathrm{p}<0.05)$ (Figs. 3 and 4). Uncured G-aenial in higher mass concentration in both test periods induced late apoptosis (Figs. 5 and 6). Uncured G-aenial Flo in both mass concentrations and both test periods induced late apoptosis and necrosis in comparison to cells of the control group ( $>0.05)$ (Figs. 5 and 6).

After 4 hours, uncured Tetric EvoCeram and uncured Tetric EvoFlow in mass concentration of 0.013 $\mathrm{g} / \mathrm{mL}$ showed a statistically significant difference in the number of micronuclei in comparison to the control group (Figs. 7 and 8). Uncured Filtek Ultimate Flow in mass concentration of $0.013 \mathrm{~g} / \mathrm{mL}$ showed genotoxic effect after 24 hours (Figs. 9 and 10). Uncured G-aenial Flo showed strong cytotoxic effect (Figs. 11 and 12).

\section{Discussion}

The present study was designed to investigate cytotoxicity and genotoxicity of six different composite materials, three flowable and three conventional ones, and to compare the results for uncured and cured forms of the materials tested. Although different tests are available, in the present study, ethidium bromide/ acridine orange viability staining and micronucleus assay were used. The advantage of ethidium bromide/ acridine orange viability staining is simplicity and ability to distinguish between apoptosis and necrosis based on DNA integrity. For genotoxicity testing, micronucleus assay is a standardized assay, which regulatory agencies consider as the official one for genotoxic effect assessment. The results of micronucleus assay show irreversible damage to genetic material, thus yielding irrefutable evidence for genotoxic effect.

The results of this study showed that all cured forms of conventional composite materials were not 
$\square$ Viable cells $\square$ Apoptotic (early) $\square$ Apoptotic (late) $\square$ Necrotic

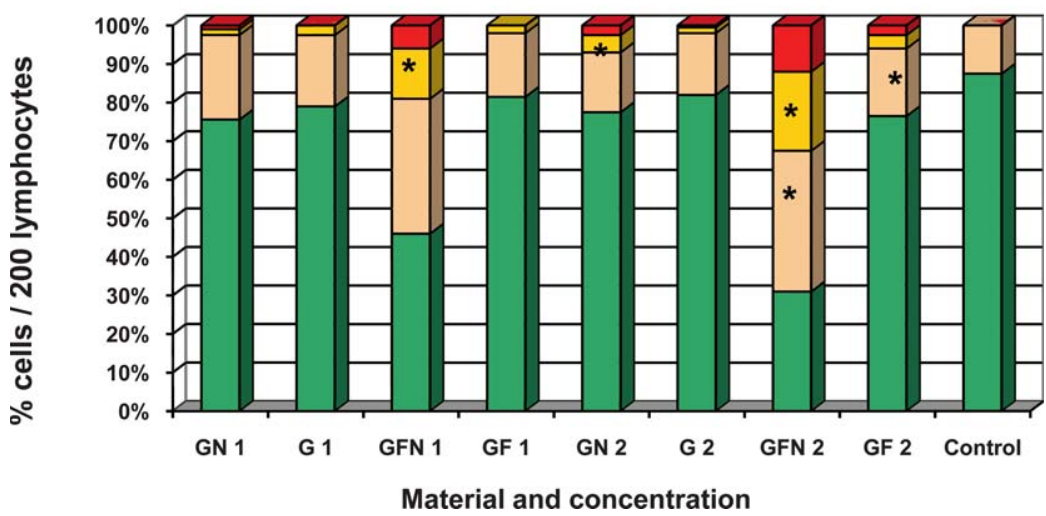

Fig. 5. Cytotoxic effect of $G$-aenial $(G)$ and $G$-aenial Flo $(G F)$ in both mass concentrations $(0.007 \mathrm{~g} / \mathrm{mL}$ (1) and $0.013 \mathrm{~g} / \mathrm{mL}$ (2)) polymerized (G1, GF1, G2, $G F 2$ ) and unpolymerized (GN1, GFN1, GN2, GFN2) after 4 hours; ${ }^{*} p<0.05$.

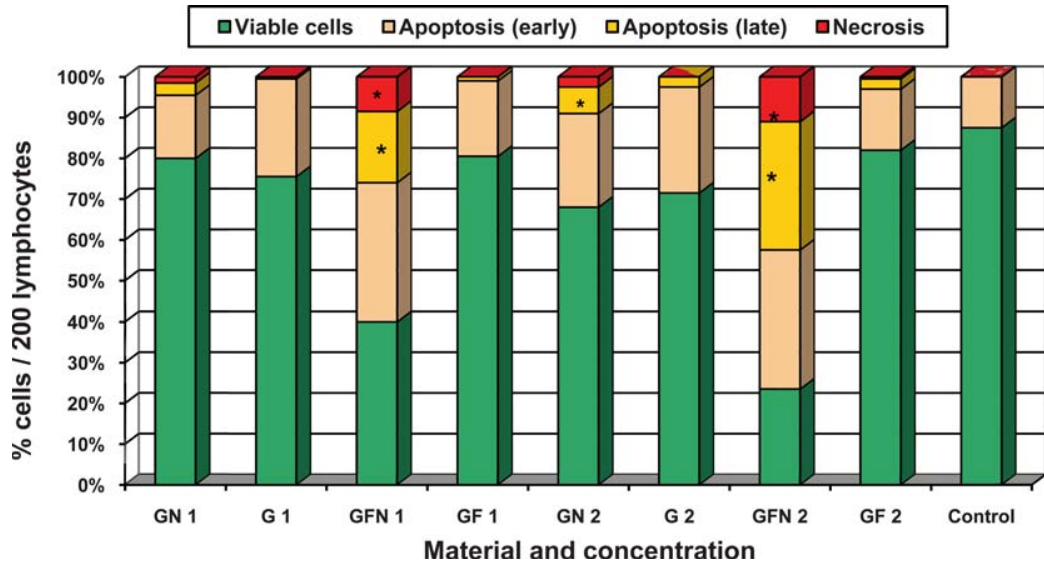

Fig. 6. Cytotoxic effect of $G$-aenial $(G)$ and $G$-aenial Flo $(G F)$ in both mass concentrations $(0.007 \mathrm{~g} / \mathrm{mL}$ (1) and $0.013 \mathrm{~g} / \mathrm{mL}$ (2)) polymerized (G1, GF1, G2, $G F 2$ ) and unpolymerized (GN1, GFN1, GN2, GFN2) after 24 hours; ${ }^{*} p<0.05$.

cytotoxic, whereas uncured forms exhibited cytotoxic effect, mainly apoptosis. Results for cured flowable composites were different from those for the conventional ones showing that cured G-aenial Flow, Tetric Evo Flow and Filtek Ultimate Flow exhibited cytotoxicity, and so did all forms of uncured flowable composites but only in higher mass concentration. Results for uncured materials were not surprising since organic components such as Bis-GMA, UDMA, TEGD$\mathrm{MA}$ and others can cause cytotoxicity in direct contact with cells. Bis-GMA has been found to cause time and concentration dependent cytotoxicity to various cell lines including human gingival and pulp fibroblasts and human THP-1 and peripheral blood monocytes ${ }^{8,9}$. TEGDMA was also found to be cytotoxic and it can easily penetrate the membranes and react with intracellular molecules ${ }^{10}$. Chang et al. ${ }^{11}$ found that UDMA decreased viability of human pulp cells and may even induce inflammation. In uncured forms of composites, these components can leach causing the cytotoxic effect.

Differences in the results between flowable and conventional composites can be explained by their different composition. Flowable composites have reduced filler loading, which modifies viscosity of these materials $^{12}$. Furthermore, they have increased levels of resin diluents that are added in order to achieve higher flow $^{13}$. These results for flowable composites are consistent with the results reported by Al Hiyasat et al. ${ }^{13}$. Hegde and Wali ${ }^{14}$ conclude that there is a significant release of BisGMA and TEGDMA resin from flowable composite materials, which can explain the higher level of cell toxicity when compared to conventional composites. It is important to emphasize that all the materials tested showed a significantly reduced cell survival by inducing apoptosis, whereas uncured G-aenial Flo induced apoptosis and necrosis. Apoptosis is a controlled process of cell death defined by nu- 


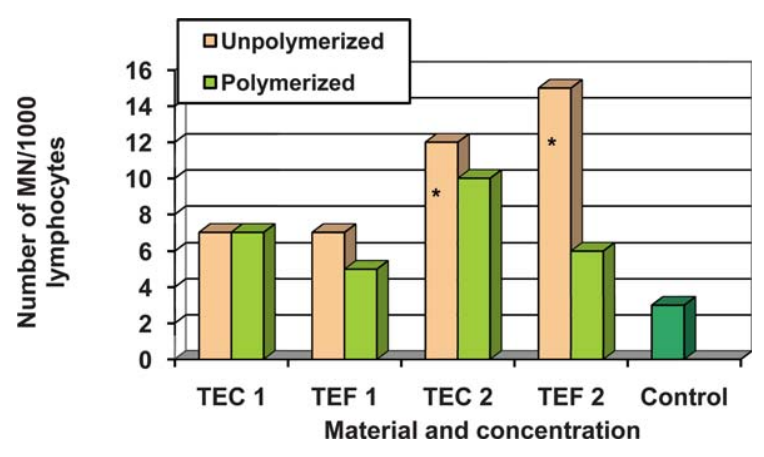

Fig. 7. Number of micronuclei in lymphocytes. Tetric EvoCeram (TEC) and Tetric EvoFlow (TEF); $0.007 \mathrm{~g} / \mathrm{mL}$ (1) and $0.013 \mathrm{~g} / \mathrm{mL}(2)$; number of micronuclei after $4 \mathrm{~h} ;{ }^{*} p<0.05$.

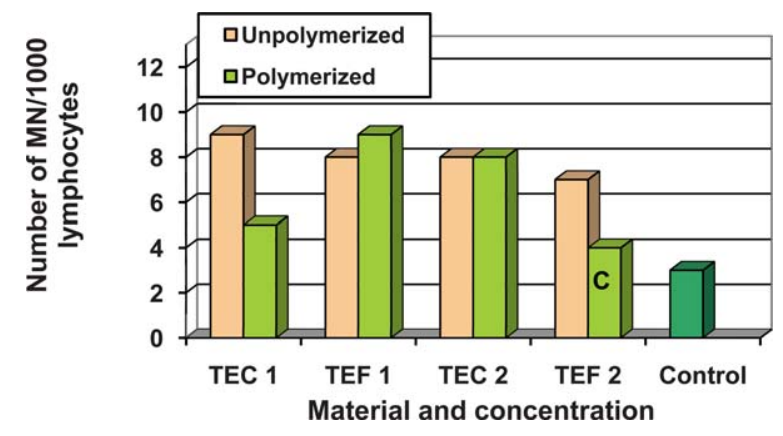

Fig. 8. Number of micronuclei in lymphocytes. Tetric EvoCeram (TEC) and Tetric EvoFlow (TEF); $0.007 \mathrm{~g} / \mathrm{mL}$ (1) and $0.013 \mathrm{~g} / \mathrm{mL}(2)$; number of micronuclei after $24 \mathrm{~h} ;{ }^{*} p<0.05 ; C=$ cytotoxic effect.

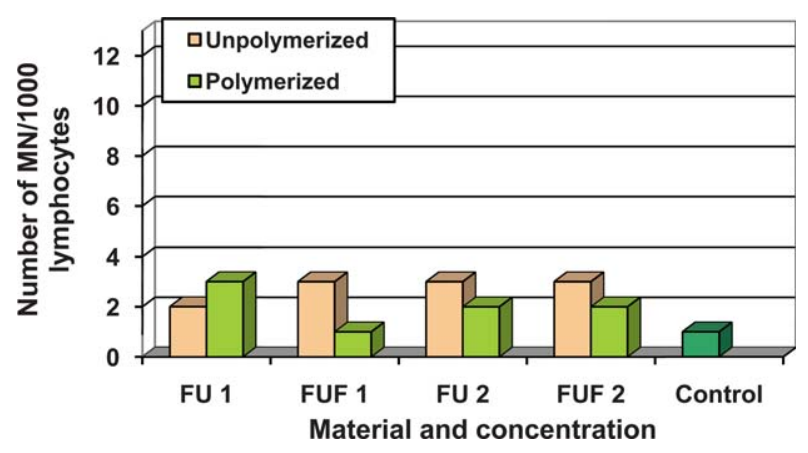

Fig. 9. Number of micronuclei in lymphocytes. Filtek Ultimate (FU) and Filtek Ultimate Flow (FUF); $0.007 \mathrm{~g} / \mathrm{mL}$ (1) and $0.013 \mathrm{~g} / \mathrm{mL}(2)$; number of micronuclei after $4 \mathrm{~h} ;{ }^{*} p<0.05$.

clear shrinkage and condensation, membrane blebbing and release of apoptotic bodies ${ }^{15}$. Stanislawski et al. ${ }^{16}$ showed that molecular mechanisms of cell apoptosis

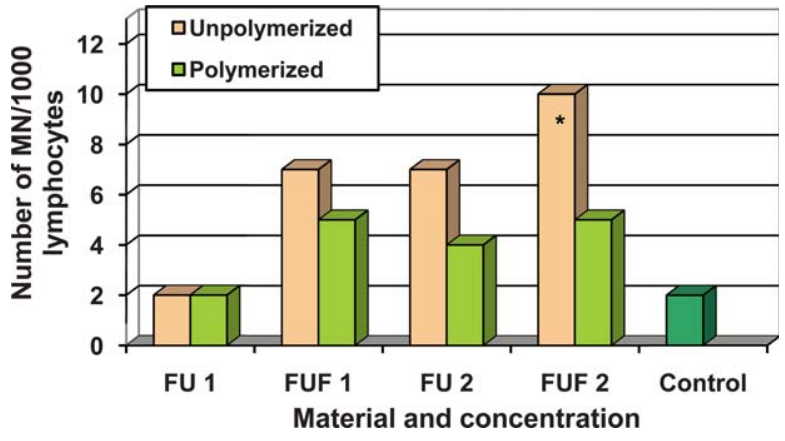

Fig. 10. Number of micronuclei in lymphocytes. Filtek Ultimate (FU) and Filtek Ultimate Flow (FUF); $0.007 \mathrm{~g} / \mathrm{mL}$ (1) and $0.013 \mathrm{~g} / \mathrm{mL}(2)$; number of micronuclei after $24 \mathrm{~b} ;{ }^{*} p<0.05$.

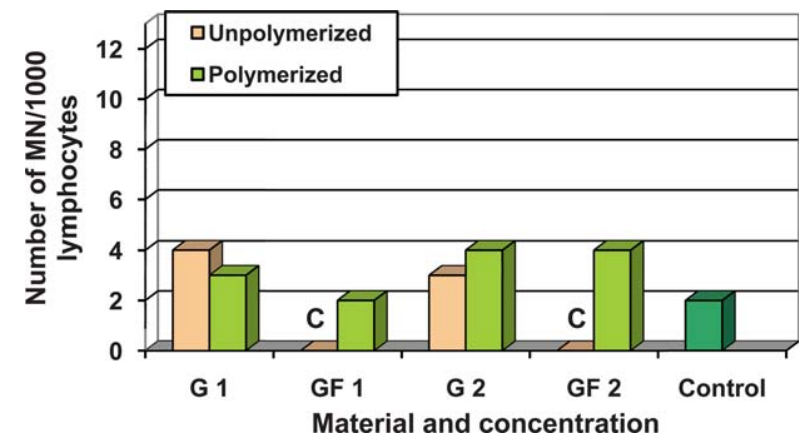

Fig. 11. Number of micronuclei in lymphocytes. $G$-aenial $(G)$ and $G$-aenial Flo (GF); $0.007 \mathrm{~g} / \mathrm{mL}$ (1) and $0.013 \mathrm{~g} / \mathrm{mL}$ (2); number of micronuclei after $4 \mathrm{~h}$; ${ }^{*} p<0.05 ; C=$ cytotoxic effect.

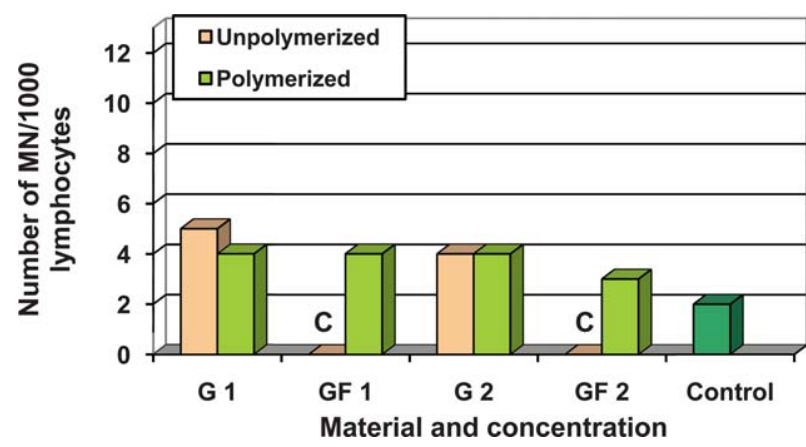

Fig. 12. Number of micronuclei in lymphocytes. $G$-aenial $(G)$ and $G$-aenial Flo $(G F) ; 0.007 \mathrm{~g} / \mathrm{mL}$ (1) and $0.013 \mathrm{~g} / \mathrm{mL}(2)$; number of micronuclei after $24 \mathrm{~b}$; ${ }^{*} p<0.05 ; C=$ cytotoxic effect.

after exposure to resin materials involved glutathione depletion and reactive oxygen species production. In contrast to apoptosis, necrosis is a passive process with 
swelling of the cell, rupture of the cell membrane followed by inflammation and therefore is a less desirable form of cell death ${ }^{15}$.

Testing of genotoxicity showed that only uncured forms of Tetric EvoCeram, Tetric EvoFlow and Filtek Ultimate Flow in higher mass concentration induced genotoxic effect on human lymphocytes, which again implies that monomers from uncured composites are responsible for genotoxic effect. Cured forms did not cause genotoxicity. It should be emphasized that genotoxicity of G-aenial could not be assessed due to the cytotoxic effect of the material which destroyed the cells. Similar to cytotoxicity, genotoxic effect is exhibited due to monomers in the composition of composite materials. It has been reported that TEGDMA and Bis-GMA monomers are often found in dental composites. The nature of the matrix monomers can influence the release of components, which have been found to be toxic ${ }^{17-20}$.

\section{Conclusion}

Under the conditions of this in vitro study, cured conventional composites did not show cytotoxic or genotoxic effect, which is important for clinical application of these materials, whereas uncured forms exhibited a certain level of cytotoxicity and genotoxicity, mainly because of the monomers in their composition.

\section{References}

1. Fong H, Dickens SH, Flaim GM. Evaluation of dental restorative composites containing polyhedral oligomeric silsesquioxane methacrylate. Dent Mater. 2005;21:520-9.

2. Yesilyurt C, Yoldas O, Altintas SH, Kusgoz A. Effects of foodsimulating liquids on the mechanical properties of a silorane based dental composite. Dent Mater J. 2009;28(3):362-7.

3. Goldberg M. In vitro and in vivo studies on the toxicity of dental resin components: a review. Clin Oral Invest. 2008;12:1-8.

4. Ferracane JL. Elution of leachable components from composites. J Oral Rehabil. 1994;21:441-52.

5. Geurtsen W. Biocompatibility of resin-modified filling materials. Crti Rev Oral Biol Med. 2000;3:333-55.

6. Darmani H, Al-Hiyasat AS, Milhem MM. Cytotoxicity of dental composites and their leached components. Quintessence Int. 2007;38:789-95.
7. Khurshid Z, Zafar M, Qasim S, Shahab S, Naseem M, AbuReqaiba A. Advances in nanotechnology for restorative dentistry. Materials. 2015;8:717-31.

8. Volk J, Engelmann J, Ley Hausen G, Geurtsen W. Effects of three resin monomers on the cellular glutathione concentration of cultured human gingival fibroblasts. Dent Mater. 2006; 22:499-505.

9. Kostoryz EL, Tong PY, Strautman AF, Glaros AG, Eick JD. Effects of dental resins on TNF-alpha-induced ICAM-1 expression in endothelial cells. J Dent Res. 2001;80:1789-92.

10. Mithra N. Hegde, Ganesh Bhat, Nagesh SC. Release of monomers from dental composite materials - an in vitro study. Int J Pharm Pharm Sci. 2012;4(3):500-4.

11. Chang HH, Chang MC, Wang HH, Huang GF, Lee YL, Wang YL, Chan CP, Yeung SY, Tseng SK, Jeng JH. Urethane dimethacrylate induces cytotoxicity and regulates cyclooxygenase-2, hemeoxygenase and carboxylesterase expression in human dental pulp cells. Acta Biomater. 2014 Feb;10(2):722-31. doi: 10.1016 j.actbio.2013.10.006. Epub 2013 Oct 17.

12. Baroudi K, Rodrigues JC. Flowable resin composites: a systematic review and clinical considerations. J Clin Diagn Res. 2015; 9(6):18-24.

13. Al-Hiyasat AS, Darmani H, Milhem MM. Cytotoxicity evaluation of dental resin composites and their flowable derivatives. Clin Oral Investig. 2005;9:21-5.

14. Hegde MN, Wali A. BisGMA and TEGDMA elution from two flowable nanohybrid resin composites: an in vitro study. Br J Med Med Res. 2015;5:1096-104. doi: 10.9734/BJMMR/2015/12951

15. Han SI, Kim YS, Kim TH. Role of apoptotic and necrotic cell death under physiologic conditions. BMB Rep. 2008 Jan 31;41(1):1-10.

16. Stanislawski L, Lefeuvre M, Bourd K, Soheili-Majd E, Goldberg M, Périanin A. TEGDMA-induced toxicity in human fibroblasts is associated with early and drastic glutathione depletion with subsequent production of oxygen reactive species. J Biomed Mater Res A. 2003;66:476-82.

17. Geurtsen W, Leyhausen G. Chemical-biological interactions of the resin monomer triethylenglycol-dimethacrylate (TEGDMA). J Dent Res. 2001;80:2046-50.

18. Martins CA, Leyhausen G, Geirtsen W, Volk J. Intracellular glutathione: a main factor in TEGDMA-induced cytotoxicity? Dent Mater. 2012;28:442-8.

19. Reichl FX, Esters M, Simon S, Seiss M, Kehe K, Kleinsasser N, et al. Cell death effects of resin-based dental material compounds and mercurials in human gingival fibroblasts. Arch Toxicol. 2006;80:370-7.

20. Chang MC, Lin LD, Chan CP, Chang HH, Chen LI, Lin HJ, et al. The effect of Bis-GMA on cyclooxygenase-2 expression, PGE2 production and cytotoxicity via reactive oxygen species and MEK/ERK dependent and independent pathways. Biomaterials. 2009;30:4070-7. 
Sažetak

\title{
CITOTOKSIČNI I GENOTOKSIČNI UČINAK KOMPOZITNIH MATERIJALA NA STANICAMA LJUDSKIH LIMFOCITA IN VITRO
}

\author{
V. Brzović Rajić, D. Želježić, A. Malčić Ivanišević, Ž. Verzak, A. Baraba i I. Miletić
}

Svrha ovoga istraživanja bila je ispitati in vitro citotoksični i genotoksični učinak šest različitih nanokompozitnih materijala, tri tekuća i tri konvencionalna kompozitna materijala na stanicama ljudskih limfocita. Istraživanje je provedeno na materijalima: Tetric EvoCeram, Tetric EvoFlow, Filtek Ultimate, Filtek Ultimate Flow, G-aenial i G-aenial Flo. Ispitivan je citotoksični učinak dviju masenih koncentracija $(0,007 \mathrm{~g} / \mathrm{mL}$ i $0,013 \mathrm{~g} / \mathrm{mL})$ svakog ispitivanog polimeriziranog i nepolimeriziranog materijala nakon 4 sata i 24 sata. Genotoksični učinak je ispitivan primjenom mikronukleus testa u istim uvjetima kao što je učinjeno u ispitivanju citotoksičnog učinka. Nepolimerizirani oblici materijala: Tetric EvoCeram, Tetric EvoFlow i Filtek Ultimate Flow u većoj masenoj koncentraciji pokazali su genotoksični učinak. Nepolimerizirani G-aenial Flo je u većoj masenoj koncentraciji izazvao apoptozu i nekrozu. U oba ispitivana razdoblja nepolimerizirani Tetric EvoFlow i nepolimerizirani Filtek Ultimate Flow su u većoj masenoj koncentraciji izazvali ranu apoptozu. Niti jedan od ispitivanih konvencionalnih materijala nije uzrokovao citotoksični učinak osim nepolimeriziranog G-aeniala koji je izazvao apoptozu u većoj masenoj koncentraciji u oba ispitivana razdoblja. Ovo istraživanje provedeno je u in vitro uvjetima. Polimerizirani oblici konvencionalnih kompozitnih materijala nisu pokazali citotoksični i genotoksični učinak koji bi bio važan za kliničku primjenu ovih materijala, dok su nepolimerizirani oblici ukazali na citotoksični i genotoksični učinak uglavnom kao rezultat djelovanja monomera koji se nalaze u sastavu kompozitnih materijala.

Ključne riječi: zubni materijali; nanokompoziti; kompozitne smole; citotoksini; apoptoza 